\title{
KEPALA SEKOLAH SEBAGAI PEMIMPIN
}

\author{
Weldan Firnando Smith
}

Balai Diklat Keagamaan Palembang

weldanfirnando@gmail.com

\begin{abstract}
Abstrak
Abstrak memuat uraian singkat mengenai tujuan penulisan, metode yang digunakan, hasil, dan kesimpulan. Abstrak ditulis maksimal dalam 200 kata. Kata kunci perlu dicantumkan untuk menggambarkan ranah masalah yang ditulis dan istilah-istilah pokok yang mendasari pelaksanaan penelitian. Kata-kata kunci dapat berupa kata tunggal atau gabungan kata/frasa. Jumlah kata-kata kunci 3-5 kata.
\end{abstract}

\section{Kata Kunci:}

\section{Abstract}

The abstract contains a brief description of the purpose of writing, the method used, and the results and conclusions. Abstract contains in a maximum of 200 words. Keywords need to be included describing the scope of the problem being written down and the main terms that underlie the conduct of the study. Keywords can be single words or combined words / phrases. The number of key words is 3-5 words.

Keywords:

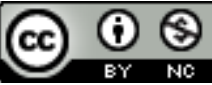




\section{PENDAHULUAN}

Membicarakan kepemimpinan dapat dimulai dari berbagai aspek dan kepemimpinan dibutuhkan oleh manusia karena adanya kelebihan dan kekurangan sudut pandang yang bebeda, dan setiap sudut pandang dapat menentukan pendekatan yang akan melahirkan pengertian yang berbeda dengan pendekatan lainnya. Hal ini berarti bahwa ada manusia yang memiliki kemampuan untuk memimpin, tetapi ada pula manusia yang tidak memiliki kemampuan untuk memimpin. Pemimpin adalah seorang yang memiliki kecakapan tertentu yang dapat memengaruhi para pengikutnya untuk melakukan kerja sama ke arah pencapaian tujuan yang telah ditetapkan. Dengan demikian, jelas bahwa pemimpin harus memiliki berbagai kelebihan, kecakapan dibandingkan dengan anggota lainnya. Dengan kelebihan yang dimilikinya, pemimpin dapat memiliki kewibawaaan sehingga dipatuhi oleh para pengikutnya. Kelebihan tersebut beragam, diantaranya ialah kelebihan moral, semangat kerja, keterampilan, kecerdasan, keuletan, dan sebagainya (turmudi, 2003:25).

Dalam praktik kepemimpinan sering dijumpai orang yang sangat berpengaruh dalam suatu organisasi dan ia tercantum secara resmi dalam organisasi tersebut sebagai pejabat, maka ia mendapat kewenangan. Orang seperti ini dikenal dengan sebutan pemimpin formal, yaitu mereka yang secara langsung diangkat dan dipilih oleh pejabat yang berwenang. Selain itu, ada juga orang yang sangat berpengaruh dalam suatu organisasi, tetapi ia tidak tercantum secara resmi dalam organisasi tersebut sebagai pejabat. Orang seperti ini dikenal dengan sebutan pemimpin nonformal, yaitu mereka yang tidak diangkat dan dipilh langsung oleh pejabat yang berwenang, tetapi yang bersangkutan mempunyai pengaruh yang sangat besar terhadap para pengikut dan warga masyarakatnya. Orang seperti ini memiliki kekuasaan, tetapi tidak memiliki kewenangan.

Pemimpin formal seperti rektor di perguruan tinggi, dekan di fakultas, kepala sekolah, kepala dinas, dan yang tertinggi presiden. Adapun pemimpin nonformal misalnya kiai di pondok pesantren, kepala suku, sesepuh desa, dan sebagainya.

Dalam perspektif sosiologis, kepemimpinan harus dilihat sebagai suatu proses atau fungsi dari pada sebagai suatu peran yang memerintah (Tannenbaum dan Fred Massarik dalam Poster, dkk, 1964:413). Ini pernah pula dikemukakan oleh (Filmore H. Sanford dalam Porter, 1964:412-413) setelah mengkaji teori-teori kepemimpinan dengan menyatakan bahwa suatu teori kepemimpinan yang komprehensif harus meliputi tiga hal, yakni (1) pemimpin dengan karakter psikologisnya, (2) para pengikut dengan masalah, sikap, kebutuhannya, (3) situasi kelompok yang pemimpin dan pengikut saling berinteraksi. Jelasnya kepemimpinan itu tidak selalu diarahkan pada pencapaian tujuan-tujuan organisasi (Hersey, 1969:111).

Pemimpin dan kepemimpinan pada dasarnya merupakan dua sisi dari satu mata uang. Oleh karena itu, pendekatan antara keduanya dapat dilakukan dari berbagai sudut. Menurut Stoner, Freeman dan Gilbert 91996:162-171), pendekatan terhadap kepemimpinan adalah:

1. Pendekatan sifat pada kepemimpinan. Pendekatan ini mengasumsikan bahwa pemimpin mempunyai beberapa sifat kepribadian yang sama yang dibawa sejak lahir. Pandangan ini bahwa pemimpin dilahirkan bukan dibuatmasih populer di antara orang banyak.

2. Pendekatan tingkah laku pada kepemimpinan. Tingkah laku, tidak seperti sifat, dapat dipelajari. Jadi, pendekatan ini mengikuti aliran bahwa individu yang dilatih dalam tingkah laku kepemimpinan yang tepat akan mampu memimpin lebih efektif. Para peneliti ini memusatkan pada dua aspek tingkah laku kepemimpinan, 
fungsi kepemimpinan dan gaya kepemimpinan.

Pendekatan kontingengsi pada kepemimpinan. Pendekatan yang menyatukan faktor-faktor dalam setiap situasi yang memengaruhi efektivitas gaya kepemimpinan tertentu disebut pendekatan kontigensi. Teori ini memfokuskan pada faktor-faktor, tuntutan tugas, harapan dan tingkah laku karyawan, budaya organisasi dan kebijakannya.

\section{METODE PENELITIAN}

\section{TEMUAN DAN PEMBAHASAN}

\section{Temuan}

\section{Pembahasan}

Sifat kepemimpinan melekat pada diri seseorang pemimpin, sehingga sering dikatakan pemimpin memiliki kepemimpinan. Pendektan perilaku kepemimpinan bukanlah ciri-ciri pemimpin yang kemudian melahirkan pola tingkah laku tertentu, tetapi keseluruhan perpaduan antara tugas, kualitas pengikut, kekuasaan yang akhirnya membentuk gaya kepemimpinan tertentu.

Meskipun demikian, pendekatan sifat dan pendekatan perilaku tidak melahirkan konsepsi baru mengenai kepemimpinan karena titik tolak perumusannya tetap sama, yaitu karakteristik mengenai seorang pemimpin. Pendekatan perilaku berlandasakan pemikiran bahwa keberhasialn atau kegagalan pemimpin ditentukan oleh gaya bersikap dan bertindak pemimpin yang bersangkutan. Pendekatan kontigensi berasumsi bahwa teknik manajemen yang baik akan memberikan bantuan terhadap pencapaian sasaran organisasi mungkin bervariasi dalam situasi yang berbeda, sehingga sering disebut dengan pendekatan situasional

Teori kepemimpinan merupakan teori yang berusaha untuk menerangkan bagaiamana pemimpin dan kelompok yang dipimpinnya dapat berprilaku dalam berbagai struktur kepemimpinan, budaya dan lingkungan. Tampaknya, para pakar kepemimpinan, secara manajerial telah banyak menawarkan berbagai teori tentang kepemimpinan tadi. Teori-teori tersebut seringkali sama dan sering kali pula berbeda.

Kepemimpinan sekurang-kurangnya dapat dibahas dalam tiga dimensi pengaruh, yaitu sebagai berikut:

1. Dimensi legitimasi, melihat posisi pemimpin dalam organisasi sosial;

2. Dimensi visibilitas, melihat tingkat pengakuan kepemimpinan seseorang, baik yang dipimpin maupun dari pemimpinnya, dan

3. Dimensi pengaruh, melihat bidang ajang atau kiprah ke pemimpinan seseorang.

Model dan gaya matriks tentang gayagaya kepemimpinan dalam bentuk suatu model analitis yang versinya dapat dipandang sebagai model-model baku. Lima gaya kepemimpinan, yaitu sebagai berikut.

1. Pemimpin otokratis (dalam Trimo, 1984:18) adalah pemimpin yang memiliki wewenang (authority) dar suatu sumber (misalnya karena posisinya), pengetahuan, kekuatan atau kekuasaan untuk memberikan penghargaan ataupun menghukum. la mengunakan authority ini sebagai pegangan atau hanya sebagai alat atau metode agar sesuatunya dapat dijalankan serta diselesaikan. Apa yang dilakukan oleh pemimpin dengan gaya ini hanyalah memberitahukan tugas bawahannya serta menuntut kepatuhan mereka secara penuh (tanpa bertanya-tanya).

2. Kepemimpinan birokratis adalah gaya kepemimpinan yang dijalankan dengan memberitahukan para anggota (bawahan) apa dan bagaimana sesuatu itu dilaksanakan. Namun demikian, dasar dari perintah tersebut hampir sepenuhnya menyangkut kebijakan, prosedur, dan aturan-aturan organisasinya. Ciri khas seorang yang birokratis adalah bahwa semua aturan atau ketentuan organisasi itu adalah 
absolut, artinya pemimpin mengatur kelompoknya dengan berpegang pada aturan-aturan yang telah ditetapkan.

3. Gaya kepemimpinan diplomatis, secara umum dapat dikatakan bahwa seorang diplomat adalah juga seorang seniman, sebagaiman seorang salesman yang melalui seninya berusaha mengadakan persuasif secara pribadi. Jadi, sekalipun ia mewakili wewenang ataupun kekuasaan yang jelas, ia kurang suka menggunakan kekuasaannya itu. la cenderung memilih cara menjual sesuatu (memotivasi) kepada bawahannya dan mereka menjalankan tugas atau pekerjaannya dengan baik. Karena itulah gaya kepemimpinan sering pula menggunakan taktik persuasif yang beragam dan bertingkat.

4. Pemimpin dengan gaya partisipatif adalah pemimpin yang selalu mengajak secara terbuka kepada para bawahannya untuk berpartisipasi atau ambil bagian, baik secara luas ataupun dalam batas-batas tertentu dalam pengambilan keputusan, perumusan kebijakn dan metode-metode operasionalnya. Jenis pemimpin seperti ini dapat berupa seorang pemimpin yang benar-benar demokratis ataupun ia berstatus sebagai pemimpin untuk berkonsultasi.

5. Free rain leader adalah pemimpin yang seakan-akan seperti menunggang kuda yang melepaskan kedua tali kendali kudanya. Walaupun dalam arti yang sesungguhnya ia bukanlah seorang pemimpin yang benar-benar membiarkan bawahannya tanpa pengawasan sama sekali, pertamatama ia menetapakan tujuan yang harus dicapai oleh anggota-anggota kelompoknya disertai dengan kebijakan tertentu, dana yang diperlukan dan jadwal pelaksaan pekerjaan atau tugas tersebut. Tindakan kedua, ia melepaskan anggota atau bawahannya untuk bebas bekerja dan bertindak tanpa pengarahan ataupun kontrol lebih lanjut, kecuali apabila mereka memintanya.

Inti teori perilaku menjelaskan bahwa dalam batas-batas tertentu, inner personality, pada dasarnya mempunyai kemampuan dalam mengembangkan kebiasaan perilakunya kepada orang lain, selama yang bersangkutan menghendaki. Oleh karena itu, untuk mengembangkan untuk mempelajari dan merealisasiakan kebiasaan yang bersifat konstruktif dalam berbagai dimensi kepemimpinannya

\section{Supervisi Pendidikan}

Istilah supervisi mempunyai pengertian luas. Supervisi adalah segala bantuan dari para pemimpin sekolah, yang tertuju pada perkembangan kepemimpinan guru-guru dan personal sekolah lainnya dalam mencapai tujuan pendidikan. Supervisi ini merupakan dorongan, bimbingan, dan kesempatan bagi pertumbuhan keahlian dan kecakapan guru-guru, seperti dalam bimbingan dalam usaha dan pelaksanaan pembaharuan dalam pendidikan dan pengajaran, pemilihan alat-alat pengajaran dan metode mengajar yang lebih baik, cara penilaian yang sistematis terhadap fase seluruh pengajaran dan sebagainya. Singkatnya, supervisi ialah suatu aktivitas pembinaan yang direncanakan untuk membantu para guru dan pegawai sekolah lainnya dalam melakukan pekerjaan mereka secara efektif

Pengembangan proses belajar-mengajar disekolah sangat erat kaitannya dengan tugas-tugas supervisor sangat multidimensional, disamping sebagai kepala, pemimpin juga pelaksana.

Supervisor bertugas member bimbingan dan penyuluhan (guidance an couselling), guna kemajuan sekolah. Oleh karena itu, yang bertugas menjadi supervisor harus bersifat lapang dada atau bijak dalam menerima berbagai saran dan kritik dari semua pihak agar setiap pengambilan keputusan

menghasilkan sesuatu yang terbaik baginkemajuan sekolah. Guru dan karyawan sekolah tanpa henti-hentinya 
diarahkan dan dibina serta dibimbing untuk mencapai kesempurnaan didalam perkerjaannya.

Tugas supervisi pertama kali dimilikimoleh pemilik sekolah. Pengawasan dilakukan ke setiap sekolah untuk menilai tingkat perkembangan dan kemajuan serta pelaksanaan berbagai kegiatan sekolah. Apabila semua guru dan karyawan sekolah telah melaksanakan admisnistrasi sekolah dengan baik, biasanya akan memperoleh penghargaan dari pemilik. Sekolah-sekolah dikompetisikan keberhasilannya dalam berbagi bidang sehingga memacu dan mendorong semua karyawan sekolah untuk semakin meningkatkan kemajuan sekolahnya.

Kemudian, kepala sekolah pun bertindak sebagai supervisi yang mengawasi, mengarahkan, membina, dan menilai kegiatan yang dilaksanakan di sekolah. Semua aktivitas dan proses belajarmengajar serta tertib-tidaknya administrasi sekolah dinilai sehingga para guru dan karyawan sekolah termasuk patner kepala sekolah dalam mengembangkan dan memajukan sekolahnya masing-masing.

Kini, disetiap sekolah dieknal dengan adanya komiyte sekolah yang secara fungsional dapat menduduki tugas supervisor. Komite sekolah dibentuk melalui musyawarah, dan pengurusnya diambil dari perwakilan orang tua atau wali. Dengan adanya komite sekolah, pengawasan terhadap kinerja administrasi pendidikan diberbagai sekolah semakin ketat, karena ada kepala sekolah yang bertugas sebagai supervisor internal dan ada komite sekolah yang berfungsi sebagai supervisor eksternal.

Supervisi diperlukan dalam proses pendidikan berdasarkan dua hal penting.

1. Perkembangan kurikulum yang merupakan gejala kemajuan pendidikan. Perkembangan tersebut sering menimbulkan perubahan-perubahan struktur maupun fungsi kurikulum. Pelaksanaan kurikulum tersebut memerlukan penyesuaian yang terus-menerus dengan keadaan nyata dilapangan. Hal ini bearti guru-guru senintiasa harus berusaha mengembangkan kreativitasnya agar pendidikan berdasarkan kurikulum itu dapat terlaksana dengan baik.

Pengembangan personal, pegawai, atau karyawan senintiasa merupakan upaya yang terus-menerus dalam suatu organisasi. Demuikian pula, halnya dengan sekolah. Kepala sekolah, guru, tenaga tata usahamemerlukan peningkatan karier, pengetahuan, dan keterampilan. Pengembangan personal ini dapat dilaksanakan formal dan informal. Pengembangan formal diselenggarakan dan menjadi tanggung jawab lembaga bersangkutan melalui penataran, tugas belajar lokakarya, dan sejenisnya. Adapun pengembangan informal merupakan tanggung jawab pegawai yang dilaksanakan secara mandiri atau bersama dengan rekan kerjannya. Teknik pengembangan jenis informal, antara lain adalah mengikuti perkembangan pendidikan melalui kepustakaan, telaahan atau percobaan suatu metode mengajar, menambah pengetahuan melalui bacaan, mengikuti kegiatan ilmiah. Hambatan terhadap upaya ini timbul karena guru-guru terlalu asyik dengan perkerjaan rutin, sarana, atau media cetak pendidikan yang langka; kurang gairah dan sikap acuh tak acuh. Untuk mengatasi masalah-masalah tersebut diperlukan bantuan yang memadai dari pihak lain. Bantuan yang bersifat membina, membimbing dan mengarahkan perkembangan para personal sekolah.

\section{PENUTUP}

Kepemimpinan kepala sekolah memegang peranan penting dalam perkembangan sekolah. Jika kepemimpinan kepala sekolah dipertaruhkan dalam proses pembinaan para guru, pegawai tata usaha, dan pegawai sekolah lainnya. Sebagai pemimpin, ia harus mengetahui, mengerti, dan memahami semua hal yang berkaitan dengan administrasi sekolah. Bahkan, ia 
harus memahami potensi yang dimiliki oleh para gurunya, sehingga komunikasi dengan para guru dan karyawan sekolah akan membantu kinerjanya, terutama untuk menyelesaikan masalah yang dihadapi oleh sekolah yang dipimpinnya.

Kepala sekolah juga harus memiliki pengetahuan dan kecakapan tinggi yang sesuai bidang tanggung jawabnya dalam sekolah tersebut, Dengan demikian, dia dapat menjalankan peranannya sebagai pimpinan organisasi yang baik. Kepala sekolah juga harus memiliki ide-ide kreatif yang dapat meningkatkan perkembangan sekolah. Dengan bantuan para guru, ia dapat mendiskusikan ide-ide tersebut untuk diterapkan ada sekolah. Bila dicapai kesepakatan antara kepala sekolah dan guru, ide-ide tersebut dapat direalisasikan.

\section{DAFTAR PUSTAKA}

Hamalik, Oemar. 2012. Manajemen Pengembangan Kurikulum. Bandung: CV. Remaja Rosdakarya. Harold, Konntz. 1986. Manajemen Jilid II, Alih Bahasa Antarikso dkk. Jakarta: PT. Erlangga. Herabudin. 2009. Administrasi dan Supervisi Pendidikan. Bandung: PT. Pustaka Setia. Purwanto, M. Ngalim. 1897. Administrasi dan Supervisi Pendidikan. Bandung: CV. Remaja Rosdakarya. Rifai, M. Moh. 1986. Administrasi dan Supervisi Pendidikan. Edisi ke-3. Bandung: PT. Jemmars. Sagala, Syaiful. 2013. Administrasi Pendidikan Kontemporer. Bandung: PT. Alfabeta. Wahjosumidjo.(2005). Kepemimpinan kepala Sekolah. Jakarta: PT. Raja Grafindo Persada. 